\title{
Ameryka Środkowa - trudne sąsiedztwo na przesmyku między Meksykiem i Ameryką Południową
}

\begin{abstract}
Artykuł omawia genezę i przebieg współczesnych granic w Ameryce Środkowej. Skupia się na historycznym procesie kształtowania się granic po upadku imperium hiszpańskiego oraz na sporach i konfliktach granicznych wynikających z roszczeń terytorialnych wobec sąsiadów. Granice państw w Ameryce Centralnej kształtowały się od czasu uzyskania przez nie niepodległości w 1821 r. i powstania Stanów Zjednoczonych Ameryki Środkowej aż do XX w., kiedy w 1903 r., w wyniku oderwania się od Kolumbii, powstało niepodległe państwo Panama. Historia siedmiu państw regionu jest burzliwa i wypełniona licznymi konfliktami granicznymi i wojnami. Ich przyczyn należy szukać m.in. w sytuacji społecznej i politycznej regionu, a głównie w kwestii braku ziemi i rozszerzającym się problemom struktury własnościowej na wsi. Szczególnie wiele uwagi poświęca współczesnym stosunkom dwustronnym i konfliktom granicznym między Nikaraguą i Kostaryką.
\end{abstract}

Słowa kluczowe: granice, konflikty graniczne, Ameryka Środkowa, Nikaragua, Kostaryka.

\section{Wstęp}

Granice państw w Ameryce Centralnej kształtowały się od czasu uzyskania przez nie niepodległości w 1821 r. i powstania Stanów Zjednoczonych Ameryki Środkowej, w długim i bolesnym procesie integracji i dezintegracji terytoriów. Od tego momentu interesy poszczególnych lokalnych polityków i dążenia separatystyczne spowodowały, że stworzone przez Simona Bolivara państwo rozpadło się, a przebieg granic między poszczególnymi republikami do dzisiaj stanowi przedmiot sporów, a nawet konfliktów zbrojnych, pomimo że siedem niepodległych republik ma wiele cech wspólnych, a ich podobieństwo opiera się na charakterystyce środowiska przyrodniczego i kultury (np. na dziedzictwie Majów).

Do historii XX w. przeszedł konflikt hondurasko-salwadorski zwany „,wojną futbolową", kiedy to po przegranym przez Honduras meczu piłki nożnej doszło do rozruchów i ofiar śmiertelnych po obu stronach granicy. Wynik meczu odbywającego się w ramach eliminacji do mistrzostw świata był tylko pretekstem do konfliktu politycznego, którego podstawy tkwiły w ekspansji osadnictwa rol- 
ników salwadorskich na tereny przygraniczne w Hondurasie. Salwador jest najgęściej zaludnionym krajem Ameryki Centralnej (średnia gęstość zaludnienia wynosi tu 324 osoby $/ \mathrm{km}^{2}$, podczas gdy w sąsiednim Hondurasie tylko $65 \mathrm{osób} / \mathrm{km}^{2}$ ) i dotkliwie odczuwa brak ziemi ornej. Honduras starał się siłą usunąć rolników salwadorskich i zmusić ich do opuszczenia kraju.

Jednak najczęściej opinia publiczna informowana jest o napięciach i akcjach sił zbrojnych Nikaragui na granicy kostarykańsko-nikaraguańskiej. Problemy graniczne, a właściwie całej strefy przygranicznej między tymi dwoma krajami stały się też obiektem debaty na forach międzynarodowych $\mathrm{z}$ momentem przystąpienia Nikaragui do budowy kanału transoceanicznego w 2014 r. Główne pytanie, które stawiają sobie naukowcy w tej sytuacji, dotyczy nie tyle kwestii geopolitycznych, ile prawa jednego małego kraju (Nikaragui) do realizowania inwestycji, mającej bardzo poważne konsekwencje dla istniejących warunków środowiska naturalnego w całym regionie, co może całkowicie zmienić istniejące tu stosunki wodne oraz florę i faunę. Kostaryka, której rozwój opiera się od trzech dekad na turystyce zrównoważonej, szczególnie zaniepokojona jest tą inwestycją.

\section{Niektóre dylematy dotyczące granic we współczesnym świecie}

Wobec rosnących w skali globalnej tendencji do integracji ekonomicznej wzrastają także działania na rzecz integracji politycznej w różnych regionach świata. W tej sytuacji funkcja i postrzeganie granicy i dyskusja na temat jej przebiegu oraz jej domknięcia lub otwarcia także podlegają ciągłym konstatacjom. M. Foucher (2005, s. 20) pyta więc, w jaki sposób teoretycznie i operacyjnie zdefiniować granicę z punktu widzenia funkcjonalnego, by wyjść poza oczywiste i konkretne sytuacje dotyczące każdej granicy analizowanej przez geografię? Granica stanowi imperatyw nieciągłości - podziałów przestrzennych, a jej funkcja zaznaczona jej znakami rzeczywistymi, symbolicznymi i wyimaginowanymi (Foucher 2005, s. 20). Funkcja dzieląca granic wynika z sytuacji danego regionu - politycznej, społecznej, ekonomicznej, lingwistycznej itd. Granice mogą dzielić terytoria homogenicznie z punktu widzenia podanych atrybutów lub zróżnicowane. Granica jest linią wyznaczającą zasięg danego terytorium. Symboliczny charakter granic odnosi się do wspólnoty politycznej zamieszkującej dane terytorium, które do niej należy i z którym się utożsamia (Foucher 2005 , s. 21). Wymiar wyimaginowany granicy odnosi się do relacji z innym (sąsiadem, przyjacielem itd.) i jest regulowany przepisami prawa.

Symboliczny charakter granicy odgrywa ważną rolę w geopolityce krajów postkolonialnych, w tym krajów Ameryki Łacińskiej. Ponieważ granice stano- 
wią linie rozdzielające czy też różnicujące relacje ciągłości między różnymi systemami politycznymi i terytoriami, to funkcje strategiczne granic polegają na obronie (ochronie) terytorium przed niepożądanymi relacjami zewnętrznymi. Oczywiście, tak jak chce M. Foucher $(2005$, s. 22) przebieg granic powinno się analizować w różnych skalach, zgodnie z celem takiej analizy. Najczęściej rekonstruuje się proces historyczny kształtowania się granic oraz wyjaśnia, jakie elementy dyskusji i argumenty geopolityczne doprowadziły od uzyskania konsensusu w kwestii jej przebiegu.

M. Foucher (2005) w swoim studium poświęca też miejsce kwestii granicy kolonialnej. Dzisiaj raczej należałoby mówić o granicy postkolonialnej. Często przedstawiana jest ona $\mathrm{w}$ analizach naukowych jako przyczyna współczesnych roszczeń terytorialnych i konfliktów, często zbrojnych. W wielu krajach, szczególnie $\mathrm{w}$ krajach afrykańskich, mamy do czynienia z granicami narzuconymi z zewnątrz, dalekimi od uwzględniania cech i elementów integrujących dane terytorium. Narzucone przez mocarstwa kolonialne granice administracji kolonialnej przekształciły się $\mathrm{w}$ granice państwowe po uzyskaniu przez te kraje niepodległości. W przypadku Ameryki Łacińskiej granice dawnych jednostek administracyjnych kolonii hiszpańskiej i portugalskiej zostały poważnie zmienione $\mathrm{w}$ wyniku działań dezintegracyjnych ze strony elit kreolskich, które przejęły władzę w niepodległych państwach w pierwszym ćwierćwieczu XIX w. W wyniku wojen o nowe tereny albo niezagospodarowane w okresie kolonialnym, albo słabo administrowane, także dochodziło do ekspansji jednych państw niepodległych na terytorium drugich - sąsiednich. W tego typu wojny były zaangażowane faktycznie wszystkie państwa w Ameryce Łacińskiej. Wielkim zwycięzcą pod względem zdobyczy terytorialnych kosztem sąsiadów okazała się w XIX w. Brazylia, która doszła do dzisiejszych rozmiarów w rezultacie wojen prowadzonych ze wszystkimi sąsiadami. Największą część swego terytorium stracił na rzecz Brazylii Paragwaj.

W przypadku wszystkich krajów dawnej kolonii hiszpańskiej proces kształtowania się terytoriów narodowych oraz elit politycznych był związany nie tylko z wojnami z sąsiadami, ale również z wojnami domowymi, gueriliami, partyzantkami różnych opcji politycznych, działaniem band i grup przestępczych. Zjawiska te występują w wielu krajach do chwili obecnej (np. w Kolumbii, Peru, Salwadorze, Hondurasie). Proces, który zachodzi w nich obecnie, to formowanie się państwa-terytorium - ,jednostki funkcjonującej politycznie, niezależnej w ramach granic wyznaczonych na mapie" (Foucher 2005, s. 24). Taka jednostka także dba o posiadanie „dobrych granic” (Foucher 2005, s. 22) - granic, które integrują terytorium państwa i ustanawiają dobre relacje $\mathrm{z}$ sąsiadami. By to osiągnąć, granice też powinny być w miarę otwarte i mieć liczne oraz nowoczesne przejścia graniczne. 


\section{Charakterystyka geograficzna regionu}

Cały obszar siedmiu krajów Ameryki Środkowej wynosi niewiele ponad 540 tys. $\mathrm{km}^{2}$. Spośród nich największe (o powierzchni ponad 100 tys. $\mathrm{km}^{2}$ ) są: Gwatemala, Honduras i Nikaragua. Natomiast najmniejsze kraje regionu, których powierzchnia nie przekracza 20 tys. $\mathrm{km}^{2}$, to Salwador i Belize (ten drugi jest jedynym krajem anglojęzycznym - to dawny Honduras Brytyjski). O ile Belize jest słabo zaludnione (przy średniej gęstości zaludnienia 14,2osób $/ \mathrm{km}^{2}$ ), o tyle wskaźnik gęstości zaludnienia w Salwadorze jest najwyższy w Ameryce Centralnej. Brak ziemi rolnej, bieda na wsi i migracje rolników salwadorskich do innych krajów regionu (także do Meksyku i USA) stanowią niewątpliwie jeden z najpoważniejszych czynników konfliktogennych w Ameryce Centralnej.
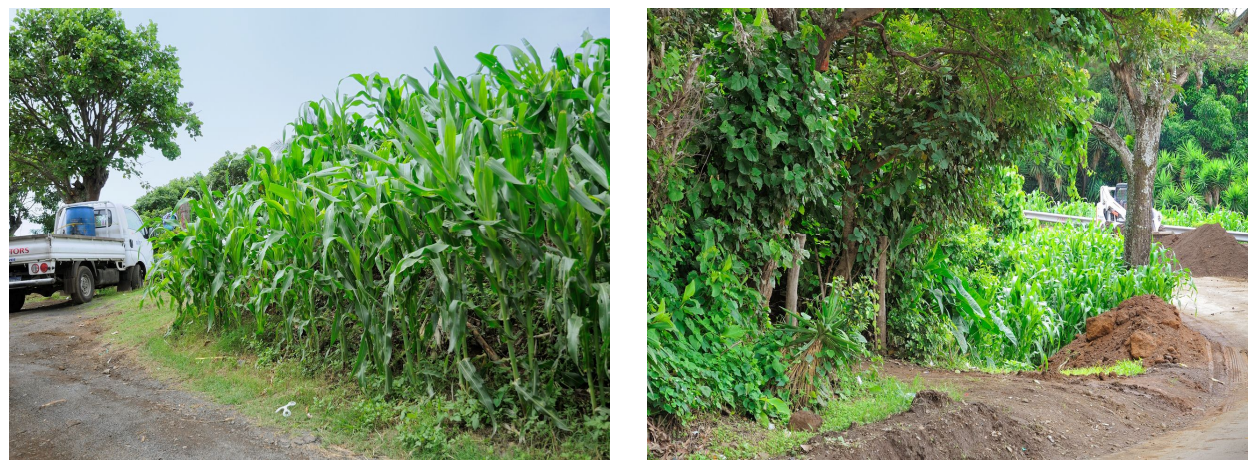

Ryc. 1-2. Jednym z najpoważniejszych problemów społecznych w Salwadorze jest brak ziemi pod uprawy. Wielkość gospodarstwa jest tak mała, że rolnicy, aby w maksymalnym stopniu wykorzystać wolne skrawki ziemi, sieją kukurydzę na poboczach dróg. Jest to prawnie zabronione, ale tolerowane przez władze Źródło: fot. M. Czerny

Obszar Ameryki Centralnej - górzysty, o zróżnicowanej roślinności i stosunkach wodnych - został dość późno skolonizowany przez Hiszpanów, którzy przybyli tu głównie jako osadnicy rolni z Meksyku lub bezpośrednio z Królestwa Hiszpanii. Granic nie wyznaczano arbitralnie (jak to było w przypadku innych kolonii hiszpańskich w Ameryce), gdyż górzyste, porośnięte trudnym do przebycia lasem tereny nie pozwalały na szybką integrację nowo zaludnionych ziem z resztą kolonii. Osadnicy wyznaczali granice swoich przestrzeni ,życiowych" sami i stopniowo poszerzali zasięg swoich posiadłości (Musset 1997). Prawdziwą ekspansję osadnictwa rolniczego kraje te, a szczególnie Kostaryka, Nikaragua i Salwador przeżywały pod koniec XIX w. i na początku XX w., w okresie coraz większego wzrostu popytu na kawę, a następnie banany na 
rynku międzynarodowym. Wtedy też popyt na ziemię i konflikty wśród osadników oraz między osadnikami i tubylcami rosły. Mamy więc tu do czynienia z sytuacją, w której granice państw są względnie stare, ukształtowane w XIX w., natomiast narody zamieszkujące poszczególne państwa nie są skonsolidowane do chwili obecnej (Musset 1997). Innymi słowy, państwa ukształtowane w wyniku wojen o niepodległość zdołały odziedziczyć i skonsolidować terytorium narodowe, ale nie naród. Różne ludy tubylcze, starzy i nowi imigranci z Europy nie byli $\mathrm{w}$ stanie określić własnej tożsamości narodowej związanej $\mathrm{z}$ danym terytorium. Ameryka Centralna stanowi prawdziwy przykład regionu, w którym można wyróżnić zarówno cechy modelu państwa europejskiego, jak i elementy kolonialne, wprowadzone do konstytucji wolnych już krajów oraz do modelu władzy ustawodawczej (Musset 1997, s. 161). Niepowodzenie ustanowienia jednego organizmu państwowego pokazuje, że model państwa narodowego narzucony przez elity polityczne pohiszpańskie, bez udziału ludności tubylczej, nie może trwać niezmiennie we współczesnym okresie. Jednocześnie nie ma wsparcia wśród mieszkańców całej Ameryki Centralnej dla silnych procesów integracji. Najbardziej są tym zainteresowani Salwadorczycy, najmniej Panamczycy i Kostarykańczycy (Musset 1997, s. 161).

Jak wspomniano powyżej, region ten cechuje się wysokim stopniem zróżnicowania środowiska przyrodniczego i stąd zapewne wynikają utrzymujące się silne regionalizmy. Skomplikowana rzeźba terenu - pas Kordyliery, przecinający cały region od Panamy do Meksyku, silnie rozczłonkowany i o stromych stokach, sprzyjał izolacji i utrudniał kolonizację i integrację w poprzednich wiekach. Duże różnice wysokości względnej wpływają również na zróżnicowanie klimatu na stosunkowo niewielkim obszarze - od strefy zwrotnikowej gorącej i wilgotnej po klimat górski i wysokogórski na szczytach wulkanów. Krajobraz wulkaniczny, z charakterystycznymi stożkami wulkanów, dominuje w zachodniej części Ameryki Centralnej. Rzeka Usumacinta (w południowym Meksyku), której dolina była silnie zaludniona już w okresie przedhiszpańskim, ma $530 \mathrm{~km}$ i przepływa dziś głównie przez terytorium Meksyku, natomiast przed przybyciem Hiszpanów stanowiła granicę kultury mezoamerykańskiej. Drugą ważną rzeką o dużym znaczeniu dla gospodarki jest Motagua (na terytorium Gwatemali). Z wyjątkiem wymienionych cieków wodnych, które są wykorzystywane do transportu wodnego towarów lokalnych z wnętrza regionu, pozostałe rzeki stanowią przeszkodę dla rozwoju gospodarczego - utrudniają handel, a brak mostów nie sprzyja integracji ekonomicznej.

Z wyjątkiem Salwadoru i Belize terytoria pozostałych krajów Ameryki Centralnej rozciągają się od wybrzeży Pacyfiku po wybrzeża Atlantyku, co w historii tych krajów odegrało ważną rolę. Towary stąd wywożone płynęły zarówno za zachód do Azji i na zachodnie wybrzeża Ameryki, jak i na wschód 
do Europy i wschodnich wybrzeży USA. Położenie większości państw na wąskim pasie lądu między dwoma oceanami stanowiło podstawy (już od czasów kolonialnych) do dyskusji na temat budowy kanału w celu usprawnienia handlu między wschodnimi i zachodnimi wybrzeżami Ameryk. Kanał Panamski powstawał na przełomie XIX i XX w., oddanie go do użytku miało poważne skutki ekonomiczne i polityczne dla regionu. Dlatego właściwie od pierwszych chwil funkcjonowania Kanału Panamskiego sugerowano konieczność budowy kolejnego przejścia wodnego łączącego dwa oceany. Plany te właśnie zaczynają być realizowane. Dzięki wsparciu firm chińskich Nikaragua przystąpiła do budowy drugiego kanału, który będzie przebiegał przez terytorium tego kraju.

W początkowym okresie kolonizacji Ameryki przez Hiszpanów, ci ostatni nie zapuszczali się w trudno dostępne tereny Ameryki Środkowej. Skomplikowana rzeźba terenu z licznymi wulkanami i stromymi stokami pokrytymi gęstym wilgotnym lasem, niebezpieczne zwierzęta - jadowite węże, pumy, owady roznoszące choroby, gorący i wilgotny klimat, nieprzyjazna Europejczykom ludność tubylcza, zamieszkująca tereny dawnego imperium Majów, sprawiały, że stałe osadnictwo hiszpańskie zaczęło tu powstawać przynajmniej dwa wieki później niż w Meksyku i w Peru. Nie odkryto tu znacznych złóż surowców mineralnych (głównie złota i srebra), jakie przyciągnęłyby osadników. Brak też istniejących struktur politycznych, które pomagały Hiszpanom w opanowaniu i administrowaniu terytoriów amerykańskich również nie stanowiło zachęty do kolonizacji rolnych tych ziem. Jedynym bogactwem regionu były i nadal są żyzne gleby powulkaniczne, na których rolnicy osiągają wysokie plony - kawy, trzciny cukrowej, kukurydzy, bawełny i innych roślin.

Niemniej jednak region Ameryki Centralnej stał się kluczowy dla dalszych losów kolonii hiszpańskiej, właśnie ze względu na swoje położenie i topografię. W 1513 r. Vasco Nuñez de Balboa po przebyciu Przesmyku Panamskiego dotarł do wybrzeża Pacyfiku, wskazując Hiszpanom dalsze możliwości ekspansji. Pięć lat później Pedro Arias Dávila (zwany też Pedrarias) założył Panamę - miasto, z którego wyruszył Francisco Pizarro na podbój Peru. Dzięki tym odkryciom powstała oś komunikacyjna i główna droga penetracji przez Hiszpanów kontynentu południowoamerykańskiego „między morzem Północnym (Atlantykiem) i morzem Południowym (Pacyfikiem), którą przewożono wszystkie skarby dawnego imperium Inków" (Musset 1997, s. 165). Tym samym Panama stała się najważniejszym miastem Ameryki Centralnej, którego znaczenie wzrosło jeszcze po wybudowaniu Kanału Panamskiego.

W wyniku stopniowej ekspansji hiszpańskiej na tereny rolnicze ludność tubylcza, szczególnie rozproszone plamiona Majów, zaczęła opuszczać żyzne obszary górskie i chronić się w niedostępnych lasach na nizinie karaibskiej, szczególnie w Petén w Gwatemali. Osadnicy brytyjscy, głównie drwale, zaczęli 
eksploatować cenne drewno z wybrzeża karaibskiego i bronili się przed atakami Hiszpanów, którzy chcieli ich stamtąd wypędzić. Był to jedyny utrzymujący się obszar niehiszpański w Ameryce Centralnej. W 1862 r. Meksyk uznał oficjalnie kolonię brytyjską Belize. $Z$ innych miejsc na wybrzeżu karaibskim, które starali się kontrolować Brytyjczycy, zostali oni wkrótce wyparci przez wojska niepodległych już państw środkowoamerykańskich (np. w $1841 \mathrm{r}$. wycofali się z wybrzeża Moskitów w Nikaragui, chociaż terytorium to uzyskało pewien rodzaj autonomii od rządu w Managui). W przypadku wysp Utila, Guanaja i Roatán, które dzisiaj należą do Hondurasu, ślady obecności Anglików spotkać można w angielskich nazwach wielu miejscowości (np. Hatch Point, Sandy Bay, Coxen Hole i innych). Przez wiele dziesięcioleci wyspy te były schronieniem dla korsarzy i piratów angielskich, napadających na statki hiszpańskie na Morzu Karaibskim.

Te i inne przykłady fragmentacji politycznej terytorium Ameryki Centralnej, wynikającej ze wspomnianych już zróżnicowanych pod względem cech środowiska naturalnego i trudnych do zagospodarowania w okresie kolonialnym regionów, zróżnicowania etnicznego, słabego wpływu miast hiszpańskich na sytuację w regionie, stałych wpływów angielskich, a później amerykańskich (przykładem tego były ogromne wpływy ekonomiczne i polityczne kompanii bananowej United Fruit Company od początku XX w.), w wielu miejscach omawianego obszaru nie przedstawiają jednak wszystkich motywów, które sprzyjały jego podziałom politycznym. Według opinii przedstawionej przez A. Musseta (1997, s. 167), dzisiejsze granice Ameryki Centralnej przebiegają $\mathrm{w}$ większości zgodnie $\mathrm{z}$ dawnymi podziałami ustanowionymi przez różne grupy konkwistadorów hiszpańskich, którzy rywalizowali między sobą o te terytoria i zdołali utrwalić podziały oparte na ich podbojach.

\section{Pochodzenie granic środkowoamerykańskich}

W wyniku odkryć geograficznych i kolonizacji Ameryki przez Hiszpanów wszystkie ziemie zajęte oficjalnie przez kolonizatorów w Ameryce Centralnej wchodziły w skład Wicekrólestwa Nowej Hiszpanii ze stolicą w mieście Meksyk. Tworzyły one, mimo różnic w charakterze środowiska naturalnego i zaludnienia, zintegrowaną jednostkę polityczną i ekonomiczną, podporządkowaną interesom Hiszpanii. W rzeczywistości też, znacznie ważniejszą od Meksyku rolę w zarządzaniu gospodarką i finansami Ameryki Centralnej odgrywała Gwatemala - siedziba Kapitanii Generalnej Gwatemali (Capitanía General de Guatemala). Terytorium Panamy, ze względu na jego znaczenie w handlu z Peru wchodziło w skład Wicekrólestwa Peru (a od 1717 r., kiedy powstało kolejne 
wicekrólestwo w Ameryce Południowej, weszło w skład Wicekrólestwa Nowej Granady). Władze Kapitanii (kapitanowie), w systemie polityczno-administracyjnym wicekrólestw hiszpańskich w Nowym Świecie miały dość dużą autonomię $\mathrm{i}$ to od sposobu rządzenia kapitana zależał poziom rozwoju danego regionu. Kapitania Generalna Gwatemali na początku XVIII w. była podzielona na 32 prowincje o zróżnicowanym statusie prawnym i administracyjnym. Najważniejsze, z punktu widzenia ich znaczenia politycznego i gospodarczego były gubernie: Camayagua, Nikaragua, Kostaryka i Soconusco. Mapa prowincji z XVIII w. sporządzona przez Nicolasa de Fer w 1702 r. posłużyła później do wyznaczenia granic między niepodległymi już państwami, które powstały po podziale jednostki politycznej zwanej Provincias Unidas de América Central (Zjednoczone Prowincje Ameryki Centralnej). Prowincja El Salvador nie była wówczas zaznaczona na mapie, a Honduras rozciągał się do Pacyfiku, zajmując część dzisiejszej Gwatemali. Granica między Hondurasem a Nikaraguą nie zmieniła się do dzisiaj od tamtych czasów.

Brak stabilizacji politycznej w regionie w okresie walk o niepodległość oraz rywalizacja między lokalnymi liderami doprowadziły do rozpadu kolejnych jednostek politycznych, które miały obejmować swoim zasięgiem cały obszar Ameryki Centralnej. Pierwsze zmiany miały miejsce w 1823 r., kiedy Ameryka Centralna oddzieliła się od Meksyku. W tym akcie dawna Kapitania Generalna Gwatemali uzyskała autonomię, ale straciła Chiapas na rzecz Meksyku. Provincias Unidas de América Central utworzyły wówczas: Gwatemala. Salwador, Honduras, Nikaragua i Kostaryka. Konstytucja federalna przyznawała każdej jednostce (prowincji) dużą autonomię. Na czele federacji stał prezydent, który urzędował w Gwatemali. Pierwszym prezydentem był Manuel José Arce i pochodził z Salwadoru. Ambicje osobiste dawnych liderów wojny o niepodległość i brak wspólnej polityki integrującej społeczeństwo młodego państwa, mimo oficjalnie głoszonej idei wielkiej ojczyzny środkowoamerykańskiej (Musset 1997, s. 172), doprowadziły do wojen wewnętrznych i w konsekwencji do rozpadu federacji w $1840 \mathrm{r}$. Nowi liderzy polityczni starali się o umocnienie legitymacji nowych republik, które pojawiły się po rozpadzie kolonii hiszpańskich poprzez propagowanie gestów i symboli nacjonalistycznych.

A. Musset (1997, s. 172) stwierdził, że główną rolę w polityce konsolidacji terytorialnej nowych republik odgrywała kartografia. Na przykład mapa wykonana w 1858 r. przez Maximiliano von Sonnenstern uważana jest za pierwszą mapę Nikaragui. Wcześniejsze mapy hiszpańskie przedstawiały całą Amerykę Środkową. Na tej mapie treść była pokazana tylko do granic państwa. Nawet obiekty liniowe (rzeki, pasma górskie) nie zostały zaznaczone na terytoriach państw sąsiednich. Geografia i kartografia były więc używane dla legitymizacji wizji geopolitycznej władzy. Dalej A. Musset (1997, s. 173) cytuje Orienta 
Bolívara Juáreza, że mapy są szczególnie ważne, gdyż dzięki nim można wykazać, że wyspy San Andrés i Providencia powinny należeć do Nikaragui oraz że terytorium kraju tworzy zwartą, niekwestionowaną całość. Przebieg granic państwowych od początku rozpadu federacji i powstania niepodległych republik w Ameryce Środkowej stanowił jeden $\mathrm{z}$ najważniejszych tematów retoryki nacjonalistycznej nowych rządów. Druga połowa XIX w., szczególnie po 1870 r., była bardzo bogata w materiały i opracowania geograficzne dotyczące charakterystyki geograficznej nowych państw. Opisywano dokładnie przebieg granic i ich punkty charakterystyczne. J. Incer (1995) cytuje opis granicy z Kostaryką z podręcznika geografii XIX-wiecznej.

Granica południowa, która nas oddziela od Republiki Kostaryki, zaczyna się w zatoce Salinas nad Oceanem Pacyficznym, skąd biegnie linią prostą do rzeki Sapoá, około dwóch mil przed jej ujściem do jeziora Nicaragua. Od tego miejsca biegnie równolegle do jeziora, zawsze w odległości około dwóch mil od jego brzegu i południowego brzegu rzeki San Juan, aż do punktu położonego około $5 \mathrm{~km}$ poniżej Castillo, punktu, w którym brzeg rzeki staje się granicą wspólną aż do jej ujścia w San Juan del Norte (Incer 1995, s. I-12).

Incer podkreśla, że rzeka San Juan znajduje się na terytorium Nikaragui, chociaż porozumienia bilateralne między dwoma państwami pozwalają Kostaryce na swobodne korzystanie z rzeki dla transportu towarów i ludzi. To jest sprzeczne z wcześniejszymi ustaleniami, że granica państwa przebiega środkiem rzeki San Juan.

Generalnie można jednak stwierdzić, że napięcia polityczne dotyczące przebiegu granic państwowych wyraźnie osłabły w drugiej połowie XX w. Na przykład w 1991 r. Gwatemala i Belize podpisały porozumienie o uznawalności granic i po raz pierwszy ustanowiły stosunki dyplomatyczne. Przez kilka następnych lat jeszcze na mapach turystycznych przedstawiano Belize jako prowincję Gwatemali. Obecnie (w 2015 r.) nie stosuje się tego procederu.

Inną strefę potencjalnego konfliktu stanowi granica Hondurasu i Salwadoru. Ostateczne porozumienie o uznawalności granic oba kraje podpisały w $1992 \mathrm{r}$. W niektórych kwestiach interweniował Międzynarodowy Trybunał w Hadze, który zadecydował na korzyść Salwadoru o przebiegu granicy na bolsonach Sazalapa-La Virtud, Tepanguisir oraz Cayanguaca. Niemniej jednak emigracja rolników salwadorskich na terytorium sąsiedniego Hondurasu może zdestabilizować sytuację na granicy obu krajów. Od lat 90. XX w. dochodzi tam czasem do incydentów zbrojnych, głównie między wojskiem Hondurasu i uzbrojonymi bandami Salwadorczyków, które przekraczają granicę.

Granica hondurasko nikaraguańska była niespokojna od momentu zwycięstwa sandinistów w tym kraju, od 1979 r. do 1990 r., w którym to roku sytuacja się ustabilizowała w wyniku wyborów przegranych w Nikaragui przez 
Front Wyzwolenia Narodowego. USA przestały wspierać opozycjonistów nikaraguańskich, którzy działali z terytorium Hondurasu, i funkcja granicy została przywrócona, chociaż Nikaragua przypomina od czasu do czasu, że jej granice sięgały dalej na północ, aż do rzeki Aguan (zwanej też Patuca).

W przypadku Nikaragui, Hondurasu, Gwatemali i Kostaryki sytuacja polityczna była napięta od połowy XIX w. do połowy XX w., kiedy kraje te wspierały partyzantów działających na granicach i zamierzających przejąc nad nimi kontrolę. Te napięcia nasilały się tam, gdzie pojawiały się interesy amerykańskich kompanii bananowych, które dążyły do przejęcia najlepszych ziem dla swoich plantacji. Przykładowo w końcu lat 20. XX w. Cuyamel Fruit Company podsycał działania partyzanckie mieszkańców Hondurasu na terytorium Gwatemali. Celem było wyparcie potężnej i dominującej w regionie United Fruit Company z terenów wzdłuż doliny rzeki Matagua i przesunięcie granicy między obydwoma krajami dalej na zachód. USA wypowiedziały się jednak po stronie Gwatemali (de facto po stronie United Fruit Company) i przeciwko Hondurasowi (czyli Cuyamel Fruit Company). Od tego czasu granica między Gwatemalą i Hondurasem została ustanowiona w wyniku porozumienia z Waszyngtonu (tzw. Laudo de Waschington) z 23 stycznia 1933 r.

Sporny charakter granic środkowoamerykańskich wynika również z faktu, że współcześni liderzy polityczni państw tego regionu starają się podkreślić nietykalność granic swoich państw, nawet wtedy, gdy ich przebieg, z punktu widzenia cech środowiska naturalnego i charakteru kulturowego wydaje się niesłuszny.

\section{Trudne sąsiedztwo kostarykańsko-nikaraguańskie}

Strefa przygraniczna kostarykańsko-nikaraguańska stanowi obszar peryferyjny, zmarginalizowany ekonomicznie, kształtowany w tym miejscu od prawie dwóch wieków. Jest to zarówno granica ekonomiczna, jak i kulturowa między dwoma sąsiadującymi ze sobą krajami. Kostaryka opisywana w literaturze po drugiej wojnie światowej jako „najbardziej biały” kraj Ameryki Środkowej (Nuhn 1991) zawsze była związana z gospodarką i kulturą europejską; w przeciwieństwie do Nikaragui, gdzie w strukturze ludności dominowali Metysi, a kraj był silnie związany $\mathrm{z}$ gospodarką i polityką północnoamerykańską. Przebieg granicy południowej kraju jest rezultatem długich negocjacji i porozumień, w których główną rolę zawsze ogrywały interesy grup postrzegających tę część Ameryki Środkowej jako strefę przyszłego kanału transatlantyckiego (Girot 1989, 1994). Koncepcja budowy kanału transoceanicznego przyznawała tej granicy rolę pomostu między interesami lokalnymi i globalnymi. Jeśli sam projekt wcześniej nigdy nie był wprowadzony w życie, to temat stanowił 
i stanowi bardziej lub mniej ukryty problem (w zależności od sytuacji polityczno-gospodarczej w krajach zainteresowanych) polityczny między Kostaryką i Nikaraguą (Sibaja 1974, Murillo 1986). W 2014 r. rząd prezydenta Ortegi podpisał jednak porozumienie $\mathrm{z}$ inwestorem chińskim i przyznał koncesję na budowę kanału. Roboty ruszyły i mają się zakończyć w 2019 r.

Transport drogą lądową między Kostaryką i Nikaraguą został otwarty dopiero w latach 50. XX w., kiedy oddano do użytku fragment drogi panamerykańskiej, który przebiega wybrzeżem pacyficznym przez oba kraje i łączy Meksyk z Panamą. Droga międzynarodowa połączyła zachodnie regiony Ameryki Środkowej, pozostawiając jednak bez dobrych połączeń komunikacyjnych środkowy i wschodni fragment granicy, a tym samym wschodnie i środkowe tereny nie tylko Kostaryki i Nikaragui, ale też Gwatemali i cały Honduras.

W przypadku Kostaryki, dopiero w połowie lat 80 . XX w. zbudowano drogę o twardej nawierzchni łączącą San José (stolicę Kostaryki) z regionem środkowo-północnym Kostaryki. Wcześniej prowadziły do niego drogi gruntowe, a do niektórych miejsc można było dotrzeć jedynie rzekami i kanałami, ewentualnie małymi samolotami, tam gdzie zbudowano pasy startowe. Inne media prąd, telefony, radio i TV dotarły tam jeszcze później (Granados, Quesada 1986).

W przypadku Nikaragui sytuacja jest podobna - rozwinięty gospodarczo oraz komunikacyjnie jest zachodni, pacyficzny region kraju, natomiast w pozostałych regionach dominuje transport wodny. Jedna droga gruntowa biegnąca przez centralną część kraju łączy Managuę z San Carlos de Nicaragua - miastem w południowej Nikaragui, na południowo-wschodnim wybrzeżu jeziora Nikaragua, w miejscu, gdzie wypływa z niego rzeka San Juan. Stan drogi uniemożliwia jednak przewóz towarów na dużą skalę. W okresie rządów członków rodziny Somozy (1936-1979) w Nikaragui cała strefa przygraniczna była wyludniona i stale kontrolowana przez wojsko. Po kostarykańskiej stronie granicy opozycja z frontu Sandino znajdowała oparcie i możliwość działania. Przez wiele lat komunikacja przez granicę była bardzo ograniczona. Jednak cały region przygraniczny przez wiele dziesięcioleci ciążył gospodarczo do miasta San Carlos na terytorium Nikaragui. Z usług w mieście korzystali mieszkańcy Upala, San Rafael de Guatuso w Nikaragui i Los Chiles po stronie kostarykańskiej (Morales Gamboa 2011).

Jako strefa o szczególnie wzmocnionej kontroli - wojskowej i ideologicznej - jej rozwój gospodarczy po obu stronach granicy był opóźniony w stosunku do pozostałych regionów, szczególnie regionu pacyficznego. Gospodarka, inwestycje publiczne, transport i komunikacja, polityka lokalna i warunki życia mieszkańców są znacznie słabiej rozwinięte $\mathrm{w}$ wyniku utrzymujących się napięć granicznych i częstych działań zbrojnych - szczególnie po stronie nikaraguańskiej (Morales Gamboa 2011). Handel w nikaraguańskiej strefie przygranicznej 
obejmuje jedynie wymianę dóbr pierwszej potrzeby oraz broni. Stan wiecznego napięcia i obecności wojsk na granicy sprzyjał rozwojowi czarnego rynku i doprowadził do upadku gospodarki regionalnej, której podstawę stanowiło tu rolnictwo tradycyjne i hodowla. Jedyne inwestycje gospodarcze, które realizowano $\mathrm{w}$ ostatnich dwóch dekadach w tej strefie, były to inwestycje wojskowe: budowa dróg gruntowych w celu umożliwienia ruchów ciężarówek i innego wyposażenia dla wojska, instalowanie obozów dla wojska i budowa magazynów wojskowych (Morales Gamboa 2011).

W ciągu ostatniej dekady sytuacja na tyle się ustabilizowała, że strefa przygraniczna Kostaryki przekształciła się w najbardziej ruchliwą strefę regionu. Setki i tysiące Nikaraguańczyków całymi rodzinami migrowały do Kostaryki w poszukiwaniu pracy. Po stronie kostarykańskiej region przygraniczny zaczął przyciągać działalność handlową i produkcyjną, szczególnie rolnictwo towarowe - plantacyjne, produkujące na eksport (ananasy, cytrusy, papaję). Już nie tylko miasteczko Los Chiles, ale także inne małe miasteczka (m.in. Santa Rosa de Pocosol, Upal) zostały wyposażane w odpowiednią infrastrukturę, głównie drogową, co ułatwiło integrację gospodarczą całego terytorium Kostaryki. Wzmocnienie ośrodków kostarykańskich osłabiło rolę miasta San Carlos po stronie nikaraguańskiej, które przestało pełnić funkcję bieguna wzrostu dla stref przygranicznych obu krajów (Morales Gamboa 2011).

Rzeka San Juan płynie po stronie nikaraguańskiej równolegle do granicy między Kostaryką i Nikaraguą. Przekroczenie granicy w jej środkowej części nie było do tej pory łatwe. Obywatele obu krajów, przekraczający granicę Nikaragui, musieli płynąć łodzią w górę rzeki Frío i po ponad pół godzinie dotrzeć do kontroli granicznej w Kostaryce. Napięcie, które trwa we wzajemnych stosunkach, pojawiło się w 2010 r., od kiedy wojska nikaraguańskie zaczęły regularnie przekraczać granicę i zapuszczać się na terytorium Kostaryki (BBC Mundo Noticias - Nicaragua, Costa Rica y el río de la discordia, 12.11.2010).

San Juan, której długość wynosi 200 km, zawsze uważana była za jedną z najważniejszych rzek w Ameryce Środkowej. W okresie kolonialnym transportowano nią towary z zachodniego na wschodnie wybrzeże kolonii, wykorzystując do tego celu także jezioro Nikaragua. Po uzyskaniu niepodległości przez państwa tego regionu znaczenie rzeki jeszcze wzrosło, głównie ze względu na pojawiające się liczne projekty budowy kanału transoceanicznego. Perspektywa zrealizowania tej inwestycji dała początek sporom granicznym między Nikaraguą i Kostaryką. W 1858 r. oba kraje podpisały traktat Cañaz-Jerez, w którym ich rządy uznały przebieg granicy. Traktat był korzystny dla Nikaragui, która zagwarantowała sobie prawo do koryta rzeki, a jednocześnie przyznawał Kostaryce swobodne prawo do wykorzystywania rzeki dla celów transportowych (z wyjątkiem okrętów wojennych). Przez prawie wiek od podpisania traktatu 
sytuacja na granicy wydawała się ustabilizowana. W 1998 r. doszło do kilku incydentów na granicy, które wynikały z różnych interpretacji ustaleń traktatu o swobodnej żegludze. Było to $\mathrm{w}$ czasie, kiedy Panama rozważała projekt poszerzenia kanału, a Nikaragua zaczęła opracowywać projekt budowy nowego. Stare projekty zostały odkurzone i stanowiły jeden z głównych argumentów w dyskursie politycznym władz nikaraguańskich dotyczących przyszłego rozwoju gospodarczego tego kraju. W 2005 r. Kostaryka wystąpiła do Trybunału Międzynarodowego w Hadze i po czterech latach (w 2009 r.) ogłoszono wyrok, w którym Trybunał uznaje suwerenność terytorium Nikaragui i wód rzeki San Juan, jednak potwierdza możliwość pełnej swobody w żegludze po rzece jednostkom kostarykańskim - handlowym, pasażerskim i turystycznym na dystansie $140 \mathrm{~km}$ żeglownego koryta rzeki na odcinku granicznym. Jednak w kampanii wyborczej w 2009 r. Daniel Ortega, ubiegający się o reelekcję na stanowisko prezydenta Nikaragui, podważył wykładnię Trybunału i wprowadził przepisy umożliwiające prowadzenie prac ziemnych - poszerzanie koryta, oczyszczanie kanałów na mokradłach w delcie rzeki. Właśnie kwestia przynależności terenów mokradeł stanowi najpoważniejszą obecnie kwestię sporną. W październiku 2010 r. Nikaragua rozpoczęła prace nad pogłębianiem rzeki na długości $33 \mathrm{~km}$. Rząd prezydenta Ortegi uzasadnił je konicznością wyczyszczenia głównego nurtu dla ułatwienia żeglugi po rzece. Władze Kostaryki twierdziły natomiast, że poszerzania i pogłębianie koryta rzeki doprowadzi do zaburzeń sieci hydrograficznej tego kraju, szczególnie w dorzeczu San Juan (Malamud, García Encina 2011). Konflikt, do wybuchu którego za pretekst posłużyła troska o jakość środowiska naturalnego, przekształcił się we wzajemne pomówienia i zarzuty o naruszanie granic państwowych i sprzyjaniu przemycaniu narkotyków przez granicę. Ten argument posłużył prezydentowi Danielowi Ortedze do wysłania wojska w strefę przygraniczną. Po interwencji Kostaryki Organizacja Państw Amerykańskich (OPA) wydała rezolucję, która zobowiązywała oba kraje do wycofania wojska i policji ${ }^{1}$ ze strefy przygranicznej.

Do 2010 r. Nikaragua nie kwestionowała też przynależności wyspy Portillos - terenu podmokłego, poprzecinanego kanałami, leżącego między laguną Portillos należącą do Nikaragui i rzeką San Juan. Nikaragua wysłała swoje wojsko w ten region i rozpoczęła kompanię na arenie międzynarodowej na rzecz uznania tego terytorium jako części jeziora Portillos, czyli należącego do Nikaragui.

Kostaryka od ponad trzech dekad wdraża w swoim kraju strategię rozwoju zrównoważonego, której głównym elementem jest dbanie i turystyczne wykorzystanie parków narodowych. Dzięki tej strategii stała się jednym z najczęściej

\footnotetext{
${ }^{1}$ Kostaryka nie posiada wojska, tylko policję.
} 
odwiedzanych przez turystów zagranicznych krajów Ameryki łacińskiej. Posunięcia Nikaragui - powiększanie terenów hodowlanych i rolniczych kosztem lasów przy granic z Kostaryką, a szczególnie promowany przez polityków projekt budowy nowego kanału transatlantyckiego przynoszą poważne zmiany i zagrożenia istniejącym ekosystemom. Skutki realizowanych w Nikaragui programów gospodarczych zagrażają bowiem istniejącym ekosystemom w Kostaryce. Do tego dochodzi kwestia penetracji terytorium Kostaryki przez zorganizowane kartele narkotykowe, które działają na linii: Honduras - Kostaryka Kolumbia. Kostaryka, z powodu braku armii, stała się łatwym terenem działań grup przestępczych.
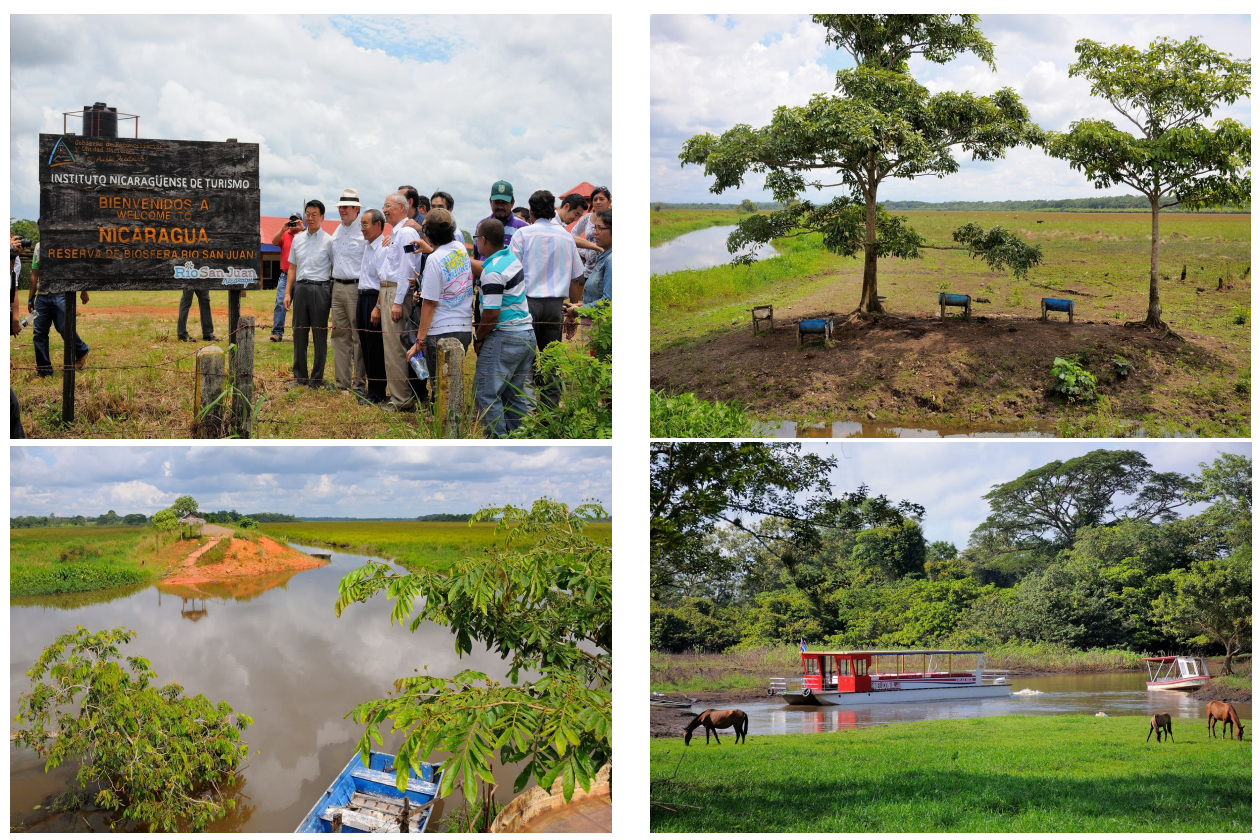

Ryc. 3. Na początku maja 2014 r. został otwarty most na rzece San Juan w Nikaragui (zwany Las Tablillas). Przeprawa ta miała ułatwić ruch osób i towarów między Kostaryką i Nikaraguą. Na zdjęciu urzędnicy nikaraguańscy i przedstawiciele firmy japońskiej, która budowała most, na granicy z Kostaryką. Towarzyszyła tej wizycie głośna muzyka, roznosząca się z ustawionych po stronie nikaraguańskiej głośników.

Piosenka, którą śpiewano, mówiła o tym, że rzeka San Juan na zawsze pozostanie w rękach Nikaragui. Rok później, w maju 2015 r. zostało wreszcie otwarte przejście graniczne między obydwoma krajami

Ryc. 4-6. Okolice Los Chiles (w Kostaryce na granicy z Nikaraguą). Podmokły, trudno dostępny region przygraniczny stanowi nie tylko obszar sporny między obydwoma krajami, ale też tereny, którędy przemycane są narkotyki

Źródło: fot. M. Czerny 
W 2014 r. Nikaragua zbudowała most na rzece San Juan, który ma ułatwić komunikację między dwoma krajami w środkowej części granicy. Otwarcie mostu było hucznie świętowane przez stronę nikaraguańską. Grupa przedstawicieli władzy w towarzystwie przedstawicieli korpusu dyplomatycznego, dziennikarzy i działaczy młodzieżowych po otwarciu mostu przyjechała do samej granicy z Kostaryką w Las Tablillas. Towarzyszyła im wielka szafa grająca, z której rozbrzmiewały słowa pieśni o tym, że rzeka San Juan jest nikaraguańska i zawsze taką pozostanie. Stali za płotem granicznym i z satysfakcją spoglądali na stronę kostarykańską. Po stronie kostarykańskiej w Las Tablillas nie było przejścia granicznego. Przekraczający most Nikaraguańczycy udawali się łodzią rzeką Frío do Los Chiles, gdzie znajduje się punkt graniczny. W 2015 r. Kostaryka otworzyła już przejście graniczne, dzięki któremu znacznie ułatwia to połączenie środkowej Nikaragui ze stolicą Kostaryki - San José. Z powodu poważnych trudności gospodarczych w Nikaragui tysiące obywateli tego kraju stara się o pracę w Kostaryce. W tym kraju przebywa już obecnie ponad 1 mln Nikaraguańczyków, co stanowi prawie 1/4 liczby mieszkańców. Dane kostarykańskiego spisu powszechnego z 2011 r. mówią o 400 tys. Nikaraguańczykach, ale wszelkie informacje nieoficjalne przytaczają znacznie wyższe liczby. Zniszczenia środowiska przyrodniczego, a tym samym degradacja terenów rolniczych, zmuszają rolników nikaraguańskich do emigracji. Pierwszym celem dla emigrantów stała się Kostaryka.

Jednak najwięcej kontrowersji wzbudza budowa nowego kanału transoceanicznego przez terytorium Nikaragui. Protesty obrońców środowiska naturalnego na całym świecie i analizy naukowe wskazują na znaczne szkody, które ta inwestycja spowoduje w środowisku naturalnym nie tylko w Nikaragui, ale też w sąsiedniej Kostaryce. W czerwcu 2013 r. Kongres Narodowy Nikaragui przegłosował projekt budowy kanału transoceanicznego, który ma przynieść temu krajowi wyższe zyski, niż przynosi Kanał Panamski Panamie. Koszt budowy ma dwukrotnie przewyższać PKB Nikaragui i wynieść ok. 50 mld US\$. Zatwierdzono projekt, który omija rzekę San Juan. Przyszły kanał rozpocznie się w porcie Brito nad Oceanem Spokojnym i zakończy w Punta Águila na wybrzeżu Morza Karaibskiego i ma mieć 278 km i 30 m głębokości; 105 km z całkowitej jego długości będzie prowadzić przez jezioro Nikaragua. Poza tym zostanie zbudowany dodatkowy sztuczny zbiornik wodny - El Atlanta na wschodzie o powierzchni $395 \mathrm{~km}^{2}$. Oprócz dwóch nowych portów infrastruktura kanału obejmie też drogę łączącą Nueva Guinea z Punta Águila, lotnisko w mieście Rivas, strefę wolnego handlu w pobliżu lotniska i kilka ośrodków turystycznych oraz cementownię i stalownię. Władze planują, że przy budowie kanału będzie zatrudnionych ok. 200 tys. osób. Planuje się także, że rocznie będzie z niego korzystać 
5100 statków $^{2}$. Budowniczymi kanału jest firma chińska z Hong Kongu HKND Group, która rozpoczęła prace w terenie w grudniu 2014 r. Prace rozpoczęto od budowy dróg do miejsc, gdzie kopany będzie kanał. Wraz z koncesją na budowę kanału firma HKDN otrzymała prawo do rozszerzania lub zmniejszania zasobów wody powierzchniowej podlegających ochronie i konserwacji ${ }^{3}$.

Naukowcy przewidują katastrofę ekologiczną wynikającą z budowy kanału. Do tej pory nie wyznaczono jego dokładnego przebiegu, a już wiadomo, że zagrożonych jest kilka cennych obszarów chronionych na wybrzeżu karaibskim (m.in. Cerro Silva $-3,4$ tys. $\mathrm{km}^{2}$ i Punta Gorda $-0,55$ tys. $\mathrm{km}^{2}$ ). Brak jest też szczegółowego opracowania dotyczącego wpływu budowy kanału na środowisko naturalne $\mathrm{w}$ tej części regionu. Zmiany w stosunkach wodnych i szaty roślinnej dotkną też Kostarykę.

\section{Podsumowanie}

Geneza państw Ameryki Środkowej i utrzymywanie się napięć wewnętrznych (guerylli, wojen domowych) oraz zewnętrznych (rewindykacji terytoriów, pobudzania uczuć patriotycznych nacjonalistycznych) pozwalają zrozumieć, dlaczego tereny przygraniczne stanowiły w przeszłości i obecnie strefy peryferyjne gospodarczo, marginalne, czerpiące niewiele korzyści z potencjalnej współpracy międzynarodowej. Przekraczanie granic lądowych $w$ regionie stanowi nadal nie lada wyzwanie dla podróżujących, np. pasażerowie autobusów na każdej granicy muszą wyjąć bagaże i poddać je kontroli, a na granicy Kostaryki i Nikaragui nawet dwa razy.

Granica kostarykańsko-nikaraguańska stanowi przykład granicy potencjalnie niestabilnej, kwestionowanej przez Nikaraguę. Sytuacji niepewności i zagrożenia granic i pojawiania się problemów społeczno-gospodarczych na obszarach przygranicznych sprzyjają różnice w poziomie rozwoju gospodarczego krajów środkowoamerykańskich oraz dynamika tego rozwoju w XXI w.

Relacje między wspomnianymi krajami stanowią też przykład poszerzenia tematyki granicznej o tematykę środowiskową. Kwestie są coraz częściej eksponowane w literaturze geopolitycznej. Wielkie inwestycje gospodarcze lub katastrofy ekologiczne sprawiają, że ich problematyka dotyka więcej niż jeden kraj. Aspiracje gospodarcze jednego kraju mogą naruszyć równowagę ekologiczną drugiego. Do chwili powstania tego artykułu brak było całościowej, kompletnej ekspertyzy, którą miała wykonać firma HKDN na temat konsekwencji budowy kanału transoceanicznego dla środowiska naturalnego w Nikaragui i Kostaryce.

\footnotetext{
${ }^{2} \mathrm{http}$ ://actualidad.rt.com/actualidad/161153-nicaragua-inauguracion-proyecto-canal

${ }^{3} \mathrm{http}: / / \mathrm{www}$. elfaro.net/es/201306/internacionales/12368/
} 


\section{Literatura}

Foucher M., 2005, Tipología de las fronteras contemporáneas, [w:] Bovin P. (red.), Las fronteras del istmo, México, s. 19-24: http://books.openedition.org/cemca/655.

Girot P., 1989, Formación y estructuración de una frontera viva: El caso de la región Norte de Costa Rica, „Geoistmo”, 3 (2), s. 17-42.

Girot P., 1994, The interoceanic canal and boundaries in Central America. The case of the San Juan River, [w:] Girot P. (red.), The Americas. World boundaries, Vol. 4, London.

Granados C., Quesada L., 1986, Los intereses geopolíticos y el desarrollo de la zona Nor-Atlántica costarricense, „Estudios Sociales Centroamericanos”, 40, s. 47-65.

Incer J., 1995, Geografía dinámica de Nicaragua, Managua.

Malamud C., García Encina C., 2011, El conflicto fronterizo entre Costa Rica y Nicaragua: ¿medioambiente, soberanía, narcotráfico o mero instrumento electoral? (ARI), Real Instituto Elcano: http:// www.realinstitutoelcano.org/wps/portal/rielcano/ contenido?WCM_GLOBAL_CONTEXT=/elcano/elcano_es/zonas_es/america+latin a/ari22-2011.

Morales Gamboa A., 2011, Cruzar la Raya: Frontera y redes sociales entre Costa Rica y Nicaragua, México, s. 267-275.

Murillo J.H., 1986, La controversia de límites entre Costa Rica y Nicaragua: el Laudo Cleveland y los derechos canaleros 1821-1903, „Anuariode Estudios Centroamericanos", 12 (2), s. 45-58.

Musset A., 1997, Las fronteras de América central: una geopolitica de larga duración, „Estudios Fronterizos. Revista del Instituto de Investigaciones Sociales”, 40, s. 159187.

Nuhn H., 1991, Zentralamerika. Ökonomische Integration und regionale Konflikte, Hamburg.

Sibaja L.F., 1974, Nuestro Límite con Nicaragua: Estudio histórico, San José.

\section{Strony internetowe}

http://actualidad.rt.com/actualidad/161153-nicaragua-inauguracion-proyecto-canal

(9.08.2015).

http://www.realinstitutoelcano.org/wps/portal/rielcano/contenido?W... (9.08.2015).

http://www.elfaro.net/es/201306/internacionales/12368/ (9.08.2015).

\section{Central America - difficult neighborhood on the isthmus between Mexico and South America}

\section{Summary}

The article discusses the origins and the course of contemporary boundaries in Central America. It focuses on the historical process of shaping the borders after the fall of the Spanish Empire as well as border disputes and conflicts arising from territorial 
claims against neighbors. The boundaries of countries in Central America developed since gaining their independence in 1821, and the emergence of the United States of Central America until the twentieth century when, in 1903, as a result of detachment from Colombia, Panama emerged as an independent state. The history of the seven countries in the region is turbulent and filled with numerous border conflicts and wars. Their causes must be sought, among others, in the social and political situation in the region mainly in the lack of land and expanding the problems of the ownership structure in the country. Special attention is paid to bilateral relationships and the border contemporary conflicts between Nicaragua and Costa Rica.

Key words: borders, border conflicts, Central America, Nicaragua, Costa Rica.

Mirosława Czerny, prof. dr hab.

Zakład Geografii Rozwoju i Planowania Przestrzennego, Wydział Geografii i Studiów Regionalnych, Uniwersytet Warszawski, 00-927 Warszawa, ul. Krakowskie Przedmieście 30 